\title{
TERMINATION OF PREGNANCY AFTER ACCELERATED LACTATION IN THE RAT
}

\author{
IV. RELATIONSHIP TO 20 $\alpha$-HYDROXYSTEROID \\ DEHYDROGENASE ACTIVITY AND PLASMA PROGESTERONE \\ CONCENTRATION
}

\author{
MARILYN J. VEOMETT AND J. C. DANIEL, JR* \\ Department of Molecular, Cellular and Developmental Biology, \\ University of Colorado, Boulder, Colorado 80302, and \\ * Department of Zoology, University of Tennessee, Knoxville, \\ Tennessee 37916, U.S.A.
}

(Received 22nd November 1974)


HSD) was assayed in the ovaries of rats after accelerated lactation to determine its relationship to the decrease in progesterone secretion that occurs. When rats were subjected to accelerated lactation on Day 9 of pregnancy, activity of the enzyme was only slightly increased by Day 10 , but had risen to twice the control level by Day 11, and three times the control level by Day 12. Administration of LH or progesterone prevented the increase in enzyme activity. Progesterone concentration had decreased considerably before the time at which any significant increase in $20 x-$ HSD activity was detected. These findings are discussed in relation to the role of $20 \alpha-\mathrm{HSD}$ in regulating progesterone levels in the rat.
\end{abstract}

\section{INTRODUCTION}

Earlier work from this laboratory has demonstrated that pregnancy is terminated in rats whose nursing litters are increased from two to nine or more on Day 9 of pregnancy (Veomett \& Daniel, 1971). Termination of pregnancy can be prevented if either progesterone or LH is administered at the time of accelerated lactation (Veomett \& Daniel, 1975b). Wiest and his colleagues have suggested that $20 \alpha$-hydroxysteroid dehydrogenase $(20 \alpha-\mathrm{HSD})$ regulates progesterone secretion in the rat, and they have implicated this enzyme as a major factor in the regulation of the progestational state of the animal (Wiest et al., 1968; Hashimoto \& Wiest, 1969; Wiest \& Kidwell, 1969). From their studies it appears that $20 \alpha-H S D$ activity is inhibited by prolactin and stimulated by LH. It was therefore of interest to determine whether changes in the activity of this enzyme might be associated with the termination of pregnancy that follows accelerated lactation in the rat. 
Animals

\section{MATERIALS AND METHODS}

Adult female albino rats were of the Holtzman strain. General maintenance and examination of implantation sites at laparotomy and at autopsy were performed as previously described (Veomett \& Daniel, 1975a). Lactation was accelerated by increasing the number of nursing young from two to ten on Day 9 of pregnancy.

\section{Hormones}

Ovine LH (NIH-LH-S17, 1.01/mg) was a gift of the Endocrine Study Section, National Institutes of Health; progesterone was obtained from Schwarz-Mann; $\left[{ }^{14} \mathrm{C}\right] 20 \alpha$-hydroxypregn-4-en-3-one was prepared enzymatically by reduction of $\left[{ }^{14} \mathrm{C}\right]$ progesterone following the procedure of Wilcox \& Wiest (1966). The ovarian extract used for this reaction was prepared by the method of Wiest (1969).

\section{Assay of $20 \alpha-H S D$}

The assay of $20 \alpha$-HSD consisted of spectrophotometric measurement of the rate of NADPH production during oxidation of $\left[{ }^{14} \mathrm{C}\right] 20 \alpha$-hydroxypregn-4-en-3one as described by Wiest (1969). Animals were killed with ether between 12.30 and 14.00 hours, and both ovaries were removed and placed in ice-cold buffer $(0.1 \mathrm{M}$-tris- $\mathrm{HCl}, 4 \mathrm{~mm}$-cysteine, $\mathrm{pH} 8 \cdot 0)$. When one uterine horn was sterile, only the ovary from the pregnant side was used. After careful trimming of extraneous tissue, the ovaries were blotted dry and weighed. They were homogenized in a glass hand homogenizer with enough buffer to make a $1 \%$ $(\mathrm{w} / \mathrm{v})$ homogenate. The homogenate was centrifuged at $4^{\circ} \mathrm{C}$ for $30 \mathrm{~min}$ at $20,000 \mathrm{~g}$ and the supernatant solution removed carefully to exclude floating fat. The amount of soluble protein in the supernatant solution was determined by the method of Lowry et al. (1951).

The reaction was carried out in a recording spectrophotometer and the rate of NADPH production was recorded for 3 to 5 min at $340 \mathrm{~nm}$. The rate was consistently linear for the first $3 \mathrm{~min}$ and the change in absorbance in a 3-min period was used to calculate the rate of NADPH production. The $\left[{ }^{14} \mathrm{C}\right]$ progesterone reaction product was isolated by paper chromatography (Dominquez, 1967) and its amount determined by liquid scintillation counting. Recovery during extraction and separation was determined by use of $\left[{ }^{3} \mathrm{H}\right]$ progesterone. The amounts of $\left[{ }^{14} \mathrm{C}\right]$ progesterone and NADPH produced in the reaction were compared and the ratio of $\mu \mathrm{mol}\left[{ }^{14} \mathrm{C}\right]$ progesterone/ $\mu \mathrm{mol}$ NADPH was recorded. In 42 assays, this ratio was between 0.71 and 1.25 in all but one case. (The results of this one assay were discarded.)

\section{Radioimmunoassay (RIA) for plasma progesterone}

Plasma collection and extraction. The animals were killed between 09.30 and 10.30 hours. Blood was collected from the heart into a heparin-coated syringe and centrifuged for $15 \mathrm{~min}$ at $1500 \mathrm{~g}$. Plasma was removed, centrifuged again and stored at $-20^{\circ} \mathrm{C}$ until assay. Two plasma samples were extracted in parallel using the procedure employed by Demetriou \& Austin (1971). Then $\left[{ }^{14} \mathrm{C}\right]$ pro- 
gesterone was added to one sample and it was checked for recovery after extraction; the second sample was used for RIA. Extracts were evaporated with a stream of air and the residue dissolved in $1 \mathrm{ml}$ absolute ethanol.

Reagents for RIA. A stock solution of phosphate-buffered saline (PBS, $\mathrm{pH} 7.4$ ) contained $8 \mathrm{~mm}-\mathrm{K}_{2} \mathrm{HPO}_{4}, 2 \mathrm{~mm}-\mathrm{NaH}_{2} \mathrm{PO}_{4} \cdot \mathrm{H}_{2} \mathrm{O}$ and $1.5 \mathrm{M}-\mathrm{NaCl}$ plus $0.38 \mathrm{~g}$ EDTA and $1.0 \mathrm{~g}$ purified calfskin gelatine (Eastman)/litre. Dextran-charcoal was prepared fresh for each RIA by mixing equal volumes of charcoal (Darco G-60, Fisher) in PBS $(5.0 \mathrm{mg} / \mathrm{ml}$ ) and Dextran T-70 (Pharmacia) in PBS $(0.5 \mathrm{mg} / \mathrm{ml})$. Progesterone antiserum was prepared by immunization of a ewe with progesterone conjugated at the 3-carbon position to bovine serum albumin. It was stored in an equal amount of glycerol at $-20^{\circ} \mathrm{C}$. A fresh solution for each assay was prepared by mixing $100 \mu \mathrm{l}$ antiserum with $12.4 \mathrm{ml}$ PBS.

RIA procedure. The procedure parallels that used by Dr F. A. Murray (personal communication). Tubes containing known amounts of progesterone dissolved in absolute ethanol and those containing samples of plasma extracts were dried with a stream of air. The following were added to each tube with mixing after each addition: (1) $200 \mu \mathrm{l} \mathrm{PBS,} \mathrm{(2)} 10 \mu \mathrm{l}\left[{ }^{3} \mathrm{H}\right]$ progesterone $\left(10^{3}\right.$ $\mathrm{ct} / \mathrm{min}$ ) in absolute ethanol, (3) $200 \mu \mathrm{l}$ antibody solution. (A control sample was prepared with PBS in place of antibody to determine the amount of $\left[{ }^{3} \mathrm{H}\right]$ progesterone that did not bind to Dextran-charcoal in the absence of antibody. This value was subtracted from all sample measurements.) Samples were incubated for $25 \mathrm{~min}$ at room temperature, then $45 \mathrm{~min}$ at $4^{\circ} \mathrm{C}$ after which cold Dextran-charcoal $(0.5 \mathrm{ml})$ was added to each tube. Tubes were again incubated at $4^{\circ} \mathrm{C}$ for $4 \mathrm{~min}$ and then centrifuged in the cold for $10 \mathrm{~min}$ at 1000 g. Samples of $0.6 \mathrm{ml}$ were counted in a liquid scintillation counter. The assay was performed in duplicate for standard and experimental samples. Standard curves were constructed by plotting the log of the amount of unlabelled progesterone against the logit of $\mathrm{B}^{*} / \mathrm{Bo}^{*}$, i.e. amount of labelled hormone bound to antibody/amount of labelled hormone bound to antibody in the absence of unlabelled hormone (Midgley et al., 1969).

\section{RESULTS}

Table 1 shows the activity of $20 \alpha$-HSD in the ovaries of rats killed between Days 9 and 12 of pregnancy. The activity decreased between Days 9 and 10 in animals nursing only two young and in those subjected to accelerated lactation. Activity continued to drop on Days 11 and 12 in the animals nursing two young, but increased greatly on Day 11 and remained high on Day 12 of pregnancy in the others.

The embryos of $3 / 5$ rats in Group 3 appeared normal on Day 10. The average enzyme activity for these three animals was $0.77 \mathrm{mu} / \mathrm{mg}$ ovary and was similar to that found on Day 10 in rats in Group 2. A fourth rat in Group 3 contained blood in the uterine lumen and the embryos were small for Day 10 of pregnancy. The fifth animal had totally resorbed its embryos. The 20 $\alpha$-HSD activities in the ovaries of these two animals were $0.90 \mathrm{mu} / \mathrm{mg}$ ovary and 1.61 $\mathrm{mu} / \mathrm{mg}$ ovary, respectively.

All experimental animals killed on Day 11 had resorbing embryos, although 
the degree of placental deterioration varied. Animals containing soft, bloody placentae, i.e. animals in which resorption was at an early stage, had higher enzyme activities than those in which only hard masses of decidual tissue were present. Four of five animals killed on Day 12 (Group 7) contained only tiny lumps of hard decidual tissue; the fifth had eight normal embryos and five resorption sites. Enzymatic activity in the latter animal was $0.58 \mathrm{mu} / \mathrm{mg}$ ovary, lower than the mean value of $1.14 \mathrm{mu} / \mathrm{mg}$ ovary found on Day 12 in the other

Table 1. Activity of ovarian 20 $\alpha$-HSD between Days 9 and 12 of pregnancy in rats subjected to accelerated lactation

\begin{tabular}{|c|c|c|c|c|c|c|c|}
\hline Group & $\begin{array}{l}\text { No. of } \\
\text { rats }\end{array}$ & $\begin{array}{l}\text { Day of } \\
\text { assay* }\end{array}$ & $\begin{array}{c}\text { No. of } \\
\text { nursing } \\
\text { young from } \\
\text { Day } 9\end{array}$ & $\begin{array}{l}\text { Ovarian } \\
\text { wt }(m g)\end{array}$ & $\begin{array}{c}\text { Ovarian } \\
\text { protein }(\mathrm{mg})\end{array}$ & $\begin{array}{c}\text { Activity of } \\
20 \alpha-H S D \\
(m u / m g \text { ovary }) \dagger\end{array}$ & $\begin{array}{l}\text { Significance } \\
\text { (t test) }\end{array}$ \\
\hline $\begin{array}{l}1 \\
2 \\
3 \\
4 \\
5 \\
6 \\
7\end{array}$ & $\begin{array}{l}4 \\
5 \\
5 \\
5 \\
5 \\
5 \\
5\end{array}$ & $\begin{array}{r}9 \\
10 \\
10 \\
11 \\
11 \\
12 \\
12\end{array}$ & $\begin{array}{r}-2 \\
10 \\
2 \\
10 \\
2 \\
10\end{array}$ & $\begin{array}{l}85 \pm 10 \\
79 \pm 7 \\
75 \pm 10 \\
84 \pm 20 \\
79 \pm 2 \\
86 \pm 11 \\
76 \pm 3\end{array}$ & $\begin{array}{l}13 \cdot 2 \pm 2.6 \\
12.3 \pm 1.6 \\
12.3 \pm 2 \cdot 6 \\
13.9 \pm 4.8 \\
11 \cdot 0 \pm 2 \cdot 0 \\
14.5 \pm 2.9 \\
12.1 \pm 1.9\end{array}$ & $\begin{array}{l}1 \cdot 26 \pm 0 \cdot 21 \\
0 \cdot 71 \pm 0 \cdot 19 \\
0.96 \pm 0 \cdot 40 \\
0 \cdot 66 \pm 0 \cdot 12 \\
1 \cdot 53 \pm 0 \cdot 34 \\
0.35 \pm 0 \cdot 08 \\
1 \cdot 14 \pm 0 \cdot 39 \ddagger\end{array}$ & $\begin{array}{l}P<0.25 \\
P<0.001 \\
P<0.005\end{array}$ \\
\hline
\end{tabular}

Values given are group Means \pm S.D.

* Animals killed between 12.30 and 14.00 hours.

$\dagger$ Value is expressed as milliunits enzyme activity/mg ovary; one unit corresponds to a production rate of $1 \mu \mathrm{mol} \mathrm{NADPH} / \mathrm{min}$.

$\ddagger$ This value represents the Mean \pm S.D. for $4 / 5$ rats in this group. A fifth animal had maintained $8 / 13$ embryos to Day 12. The enzyme activity for this animal was $0.58 \mathrm{mu} / \mathrm{mg}$ ovary.

Table 2. Activity of ovarian 20 $\alpha$-HSD on Day 11 (12.30 to 14.00 hours) of pregnancy in rats receiving hormone treatment after accelerated lactation begun on Day 9

\begin{tabular}{|c|c|c|c|c|c|}
\hline Group & Treatment & $\begin{array}{l}\text { No. of } \\
\text { rats }\end{array}$ & $\begin{array}{c}\text { Ovarian } \\
w t(m g)\end{array}$ & $\begin{array}{c}\text { Ovarian } \\
\text { protein }(m g)\end{array}$ & $\begin{array}{c}\text { Activity of } \\
20 \alpha-H S D \\
(m u / m g \text { ovary })^{*}\end{array}$ \\
\hline 1 & $\begin{array}{l}4 \mathrm{mg} \text { progesterone/day, } \\
\text { on Days } 9,10,11\end{array}$ & 4 & $71 \pm 6$ & $12 \cdot 3 \pm 0 \cdot 9$ & $0 \cdot 51 \pm 0 \cdot 18$ \\
\hline 2 & $\begin{array}{l}100 \mu \mathrm{g} \text { LH in gelatine } \\
\text { on Days } 9,10\end{array}$ & 4 & $105 \pm 11$ & $16 \cdot 5 \pm 1 \cdot 9$ & $0.48 \pm 0.20$ \\
\hline
\end{tabular}

Values given are group Means \pm S.D.

* Value is expressed as milliunits enzyme activity/mg ovary; one unit corresponds to production rate of $1 \mu \mathrm{mol} \mathrm{NADPH} / \mathrm{min}$.

rats in Group 7, but higher than the mean value of $0.35 \mathrm{mu} / \mathrm{mg}$ ovary found on Day 12 in rats in Group 6; the value is within the range of two standard deviations of the higher mean value.

The activity of $20 \alpha-\mathrm{HSD}$ on Day 11 in animals treated with progesterone or $\mathbf{L H}$ after accelerated lactation is shown in Table 2. Both hormone treatments prevented embryo resorption and the increase in enzyme activity seen on Day 11 in rats nursing ten young and receiving no hormone treatment (Table 1, 
Group 5). Ovarian weight and protein content were increased after 2 days of LH treatment.

The progesterone concentration found in peripheral plasma between Days 9 and 11 of pregnancy is shown in Table 3 . Animals were killed earlier in the day than in the previous experiments; therefore, $20 \alpha-\mathrm{HSD}$ activity was also measured since it was expected that enzyme activity might be different at this time. (The stoichiometry of NADPH and progesterone production was not determined.) Enzyme activities found in these animals were similar to those found in the previous experiment, although activities found on Day 9 and on Days 10 and 11 after accelerated lactation were somewhat lower. Plasma progesterone concentration decreased gradually between Days 9 and 11 in control animals, but had decreased dramatically by Day 10 in animals that experienced accelerated lactation.

Table 3. Plasma progesterone concentrations between Days 9 and 11 of pregnancy in rats subjected to accelerated lactation from Day 9

\begin{tabular}{|c|c|c|c|c|c|c|}
\hline Group & $\begin{array}{l}\text { Day of } \\
\text { assay* }\end{array}$ & $\begin{array}{l}\text { No. of } \\
\text { rats }\end{array}$ & $\begin{array}{c}\text { No. of } \\
\text { nursing } \\
\text { young after } \\
\text { Day } 9\end{array}$ & $\begin{array}{c}\text { Activity of } \\
20 \alpha-H S D \\
(m u / m g \text { ovary }) \dagger\end{array}$ & $\begin{array}{c}\text { Plasma } \\
\text { progesterone } \\
\text { conc. }(n g / m l)\end{array}$ & $\begin{array}{l}\text { Significance } \\
(\mathrm{t} \text { test })\end{array}$ \\
\hline $\begin{array}{l}1 \\
2 \\
3 \\
4 \\
5\end{array}$ & $\begin{array}{r}9 \\
10 \\
10 \\
11 \\
11\end{array}$ & $\begin{array}{l}3 \\
4 \\
4 \\
3 \\
3\end{array}$ & $\begin{array}{r}- \\
2 \\
10 \\
2 \\
10\end{array}$ & $\begin{array}{l}1.01 \pm 0.08 \\
0.57 \pm 0.13 \\
0.68 \pm 0.18 \\
0.64 \pm 0.02 \\
1.24 \pm 0.32\end{array}$ & $\begin{array}{r}132 \cdot 6 \pm 8 \cdot 7 \\
130 \cdot 0 \pm 36 \cdot 4 \\
53 \cdot 3 \pm 22 \cdot 3 \\
93 \cdot 5 \pm 6 \cdot 8 \\
64 \cdot 0 \pm 24 \cdot 3\end{array}$ & $\begin{array}{l}P<0.02 \\
P<0.20\end{array}$ \\
\hline
\end{tabular}

Values given are group Means \pm S.D.

* Animals killed between 09.30 and 10.30 hours.

$\uparrow$ Value is expressed as milliunits enzyme activity/mg ovary; one unit corresponds to a production rate of $1 \mu \mathrm{mol} \mathrm{NADPH} / \mathrm{min}$.

\section{DISCUSSION}

The experiments in which $20 \alpha$-HSD activity was measured from Days 9 to 12 in animals that had been subjected to accelerated lactation suggested that the stimulation of activity of this enzyme could be the cause of pregnancy termination by decreasing progesterone secretion. Activity of the enzyme was only slightly higher by the afternoon of Day 10 in rats that had experienced accelerated lactation in comparison to control rats, but had risen to more than twice the control level by the afternoon of Day 11 and three times the control level by Day 12. These findings correlate well with the fact that only 1 day of accelerated lactation often does not result in pregnancy termination whereas 2 days of accelerated lactation do (Veomett \& Daniel, 1975a).

It was expected that $\mathrm{LH}$ administration had prevented termination of pregnancy either by preventing the increase in $20 \alpha$-HSD activity or by increasing progesterone synthesis to a level high enough that sufficient progesterone was still secreted despite activity of $20 \alpha$-HSD. It was expected that progesterone prevented pregnancy termination either because exogenously administered progesterone was not susceptible to catabolism by the ovary or 
because progesterone levels were high enough to allow for considerable catabolism. When the former question was tested, it was found that LH administration prevented the increase in $20 \alpha$-HSD activity, and the activity on Day 11 was slightly lower than in control rats. It was unexpected, however, that progesterone administration would have the same effect on $20 \alpha$-HSD activity. Thus it was possible that the activity of $20 \alpha$-HSD might be influenced directly by progesterone levels and only indirectly by $\mathrm{LH}$, i.e. only insofar as LH was stimulatory to progesterone synthesis.

To test this possibility, $20 \alpha$-HSD activity and plasma progesterone concentration were measured concurrently after accelerated lactation. The results clearly indicated that plasma progesterone concentration had decreased considerably before the time at which any significant increase in $20 \alpha-\mathrm{HSD}$ was detected. Consequently, increased activity of this enzyme could not be responsible for at least the initial decrease in progesterone secretion. Since progesterone was measured in peripheral plasma as opposed to ovarian venous blood, it is also possible that the decline in progesterone secretion could be partly of adrenal origin.

Since 1 day of accelerated lactation does not normally terminate pregnancy, it seems likely that the decline in progesterone secretion resulting from accelerated lactation is not irreversible, at least initially. Likewise, such a temporary decline in progesterone secretion must not be detrimental to pregnancy. It is possible, however, that increased activity of $20 \alpha-\mathrm{HSD}$ does result in an irreversible decline in progesterone secretion and thereby plays an important role in ensuring termination of pregnancy. This irreversible decline could result either from conversion of progesterone to $20 \alpha$-hydroxypregn-4-en-3-one by the scheme of Wiest $e t$ al. (1968) or by the novel progesterone-bypass pathway suggested by Kuhn \& Briley (1970) in which 20 $\alpha$-HSD converts pregnenolone to pregn-5ene-3 $\beta, 20 \alpha$-diol which is then converted to $20 \alpha$-hydroxypregn-4-en-3-one by $\Delta^{5}-3 \beta$-hydroxysteroid dehydrogenase.

These results lead to modification of the hypothesis that progesterone secretion and thereby progestational potency in the rat are regulated by $20 \alpha-$ HSD activity and that activity of this enzyme is, in turn, controlled by prolactin and LH (Wiest et al., 1968; Wiest \& Kidwell, 1969). Although activity of this enzyme can be altered by administration of LH or prolactin, or compounds that decrease serum levels of these proteins, such as antiserum to $\mathrm{LH}$ and ergocornine, these effects may be due to the more direct effect of prolactin and $\mathrm{LH}$ on progesterone synthesis. Under conditions where prolactin or LH depress progesterone synthesis, the activity of $20 \alpha$-HSD would be increased; when these hormones increase progesterone synthesis, the $20 \alpha$-HSD would be decreased. Thus, instead of prolactin or LH altering 20 $\alpha$-HSD activity, which in turn alters progesterone secretion, we suggest that prolactin or LH alters progesterone secretion which then alters $20 \alpha$-HSD activity. The role of $20 \alpha$-HSD would be more one of stabilizing progesterone secretion at a particular level rather than initiating changes in its secretion. For example, pituitary hormone stimulation could result in lowered progesterone production. An increase in 20 $\alpha$-HSD activity in response to this depression of progesterone level would ensure low production of progesterone without continued pituitary action being required. 
Such an hypothesis would explain some of the confusing findings regarding the effects of prolactin and LH on $20 \alpha-\mathrm{HSD}$ activity. For example, prolactin administration causes a decrease in the secretion of 20 -hydroxy-pregn-4-en-3one to animals in which progesterone secretion is low, and could thus be stimulated by prolactin, i.e. in the latter part of dioestrus, pseudopregnancy or lactation, but is much less effective when progesterone production is at a high level, i.e. early in lactation (Hashimoto \& Wiest, 1969; Yoshinaga et al., 1971). The effect of LH on $20 \alpha$-HSD activity also varies with the reproductive state of the animal. Administration of antiserum to LH on Day 7 of pregnancy results in an increase in $20 \alpha$-HSD activity and a decrease in progesterone (Loewit et al., 1969; Moudgal et al., 1972). Yet LH antiserum administered later in pregnancy (Day 14) does not significantly depress progesterone secretion, presumably because of the action of placental luteotrophin, and causes no increase in secretion of 20 $\alpha$-hydroxypregn-4-en-3-one (Moudgal et al., 1972).

It is known that $20 \alpha-\mathrm{HSD}$ activity may increase when pituitary hormones cannot have a causal effect. Enzyme activity rises dramatically at parturition, even in hypophysectomized rats, and this has been considered to be due to loss of placental support at this time leading to a decline in progesterone secretion. Rats hypophysectomized on Day 11 of pregnancy have large increases in the activity of $20 \alpha-H S D$ activity following either complete placental dislocation or hysterectomy on Day 13 of pregnancy (Wiest et al., 1968). Again, the increase in enzyme activity may simply result from a reduction in progesterone production due to the loss of support from placental luteotrophin.

\section{ACKNOWLEDGMENTS}

This work was supported by an Institutional Research Grant, No. IN-103, to the University of Colorado and by a National Defense Education Act Title IV grant No. 69-00467. We are most grateful to Dr Meredith Runner for providing equipment, laboratory space and advice during this work. The antiserum to progesterone was a gift of Dr F. A. Murray of the University of Tennessee.

\section{REFERENCES}

Demetriou, J.A. \& Austin, F.G. (1971) A rapid competitive protein-binding assay for plasma progesterone. Clin. chim. Acta 33, 21-32.

Dominguez, O.V. (1967) Chromatography of steroids on paper. In Steroid Hormone Analysis, Vol. I, pp. 135-318. Ed. H. Garstensen. Marcel Dekker, New York.

Hashrmoto, I. \& WIEST, W.G. (1969) Luteotrophic and luteolytic mechanisms in rat corpora lutea. Endocrinology 84, 886-892.

KunN, N.J. \& BRILEY, M.S. (1970) The roles of pregn-5-ene-3 $\beta$-20 $\alpha$-diol and $20 \alpha$-hydroxysteroid dehydrogenase in the control of progesterone synthesis preceding parturition and lactogenesis in the rat. Biochem. F. 117, 193-201.

LoEWTT, K., BADAWY, S. \& LAURENCE, K. (1969) Alteration of corpus luteum function in the pregnant rat by antiluteinizing serum. Endocrinology 84, 244-251.

Lowry, O.H., Rosebrough, N.J., FarR, A.L. \& Randall, R.J. (1951) Protein measurement with the Folin phenol reagent. F. biol. Chem. 193, 265-275.

Midgley, A.R., JR, Niswender, G.D. \& Rebar, R.W. (1969) Principles for the assessment of the reliability of radioimmunoassay methods. Acta endocr., Copenh. 63, Suppl. 142, 163-180.

Moudgal, N.R., Behrman, H.R. \& GREEP, R.O. (1972) Effect of luteinizing hormone antiserum on progesterone and $20 \alpha$-dihydroprogesterone secretion in the pregnant rat. $\mathcal{F}$. Endocr. 52, 413-418. 
Veometr, M.J. \& Daniel, J.C., JR (1971) Termination of pregnancy after accelerated lactation in the rat. F. Reprod. Fert. 26, 415-417.

Veomett, M.J. \& Daniel, J.C., JR (1975a) Termination of pregnancy after accelerated lactation in the rat. II. Relationship to number of young, day of pregnancy and length of nursing. F. Reprod. Fert. 44, 513-517.

Veometr, M.H. \& DANiEL, J.C., JR (1975b) Termination of pregnancy after accelerated lactation in the rat. III. Effects of hormonal treatments. J. Reprod. Fert. 44, 529-536.

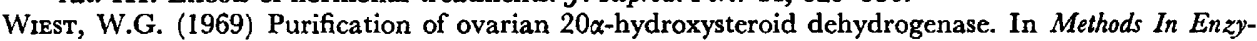
mology, Vol. 15, pp. 638-641. Ed. R. B. Clayton. Academic Press, New York.

WIEsT, W.G. \& KiDWEL., W.R. (1969) The regulation of progesterone secretion by ovarian dehydrogenases. In The Gonads, pp. 295-325. Ed. K. W. McKerns. Appleton-Century-Crofts, New York.

Wiest, W.G., Kidwelr, W.R. \& Balogh, K., JR (1968) Progesterone catabolism in the rat ovary: a regulatory mechanism for progestational potency during pregnancy. Endocrinology 82, 844-859.

WILcox, R.B. \& WIEst, W.G. (1966) Further studies of rat ovarian $20 \alpha$-hydroxysteroid dehydrogenase. Steroids 7, 395-413.

Yoshinaga, K., Moudgal, N.R. \& Greep, R.O. (1971) Progestin secretion by the ovary in lactating rats: effect of luteinizing hormone-antiserum luteinizing hormone and prolactin. Endocrinology 88, $1126-1130$. 